\author{
Svitlana Polshkova \\ Oleg Chaban
}

\title{
FACTORS PROLONGING THE PERIOD OF SOBRIETY IN YOUNG PATIENTS WITH ALCOHOL USE
}

Polshkova S., Chaban O. Factors prolonging the period of sobriety in young patients with alcohol use. Alcohol beverages became a regular part of the everyday life of society. This is particularly true for those in social environments when alcohol is using for socializing. Due to this fact, it is easy to fail to notice the health and social damage caused by alcohol drinking.

In the pilot study we examined the feasibility and initial efficacy of a brief intervention on reducing risky drinking among emerging adults in Ukraine. Patients were evaluated in 3 months after the brief motivational intervention (BMI).

We included patients who successfully completed the pilot study (all of them had an opportunity to visit our clinic after completing the study for free if necessary). We had 2 groups of participants: (1-st group - young patients of Railway Clinical Hospital, with risky drinking (AUDIT-C> 5); and, 2-nd group - students of the National Medical University OO Bogomolets, with risky drinking (AUDIT-C> 5). All participants were evaluated using set of tests (Structured Interview (personal data, substance use, substance use treatment history, medical history), AUDIT-C, RAPI, DMQ, Quality of Life Scale (O. Chaban, 2009), BSSS, PHQ-9, GAD-7, BPAQ$S F)$ in 4 years after taking part in a pilot study when they obtained BMI. We also evaluated many factors including the frequency of participants' visits to our clinic after completing the pilot study.

Participants from the university setting were significantly younger, and single (as opposed to married), with fewer children comparing to participants in the hospital setting. Regression analyses were conducted, separately for each setting, predicting alcohol outcomes (consumption and consequences). In both settings, the brief intervention group (BI group) showed significantly less alcohol consumption and consequences after 4 years period compare to the control group $(p<0.001)$. However university group showed more cases of sobriety disruption during this period. Among the BMI sample showed lower level of depressive and anxiety symptoms according to PHQ-9 and GAD-7 scales, relative to the control group. Also, the brief intervention group showed a higher level of quality of life relative to the control group. Also the aggression level was different in BMI and control groups (control group showed higher level of aggression). However, there are some differences between patients and students samples with BMI in the results of quality of life scale. This result can be related to the quality of sobriety period in these groups and to the presence of higher level of aggression (including indirect aggression - guilty feelings, according to BPAQ-SF) in students sample.

The data obtained indicate that BMI are promising for reducing risky drinking among emerging adults in the Ukraine in both settings (patient hospital and university).

Key Words: motivational interview, youth, adolescents, alcohol, factors prolonging sobriety

Полшкова С., Чабан О. Фактори, які сприяють подовженню періоду тверезості серед молоді, щцо вживають алкоголь. Останнім часом алкогольні напої стали регулярною частиною повсякденного життя суспільства. Особливо ие стосується тих, у кого в їхньому соціальному середовищі алкоголь вживається для спілкування та соџіалізації. Через ие досить помітно, яку шкоду здоров'ю та соціальному життю спричиняє вживання алкоголю. 
У пілотному дослідженні вивчено можливості та ініціальну ефективність короткого втручання щодо зменшення ризику вживання алкоголю серед дорослих в Україні. Пацієнтів оцінювали через 3 місячі після коротких мотиваційних інтервенцій (КМІ або коротких інтервенцій - KI).

В дослідженні використано наступні методи: сруктуроване інтерв'ю (особисті дані, вживання речовин, історія лікування вживання речовин, історія хвороби), AUDIT-C (Alcohol Use Disorders Identification Test-Concise - шкала з 3 запитань для скринінгу пацієнтів із проблемним вживанням алкоголю, щзо є модифікацією повної шкали AUDIT з 10 запитань), RAPI (Rutgers Alcohol Problems Index - ие інструмент для скринінгу (опитувальник) з 23 запитань для очінювання алкогольних проблем серед підлітків), DMQ (Drinking Motives Questionnaire - це опитувальник на 28 пунктів, щзо вимірює 5 мотивів пиття: соиіальне "покращення", зменшення відчуття депресії, протитривожний мотив та почуття відповідності), шкала якості життя (О. Чабан, 2009), BSSS (Brief Sensation Seeking Scale - шкала, яка допомагає ідентифікувати осіб, щчо шукають гострі почутті, як то ризикована поведінка, вжсивання алкоголю $i$ т.ін.), PHQ -9 (Patient Health Questionnaire-9 - опитувальник для діагностики депресіi), GAD-7 (General Anxiety Disorders -7 - опитувальник для діагностики тривожних розладів), BPAQ-SF (Buss-Perry Aggression Quеstionnaire - опитувальник для очінки агрессіі). Ми також очінили багато факторів, в тому числі частоту відвідувань учасниками нашої клініки після завершення пілотного дослідження.

Доведено, щуо группа коротких інтервенцій (група КI) показала значно менший рівень спожсивання алкоголю та наслідки після 4-річного періоду порівняно з контрольною групою ( $p<0.001)$. Однак університетська группа показала більше випадків порушення тверезості в ией період. Серед зразків КМІ було виявлено нижчий рівень депресивних та тривожних симптомів за шкалами PHQ-9 та GAD-7 відносно контрольної групи. Також группа коротких інтервенцій виявила більш високий рівень якості життя відносно контрольної групи. Також рівень агресії був різним у КМI та контрольних групах (контрольна группа показала більш високий рівень агресії). Однак, є деякі відмінності між группами пацієнтів та студентів з КМІ в результатах икали якості життя. Цей результат може бути пов'язаний з якістю періоду тверезості в цих группах та з наявністю вищого рівня агресії (включаючи непряму агресію - почуття вини, згідно BPAQ-SF) у вибіриі студентів.

Показано, що отримані дані свідчать про перспективність КМI як засобу для зниження ризикованого вживання алкоголю серед молоді в Украӥні.

Ключові слова: мотиваційне інтерв'ю, молодь, підлітки, алкоголь, фактори, щэо продовжують тверезість.

Поликов С., Чабан А. Факторы, которые способствуют удлинению периода трезвости среди молодежи, употребляющих алкоголь. В последнее время алкогольные напитки стали регулярной частью повседневной жизни общества. Особенно это касается тех, у кого в их сочиильной среде алкоголь употребляется для общения и сочиализачии. Изза этого довольно заметно, какой вред здоровью и сочиильной жизни вызывает употребление алкоголя.

В пилотном исследовании изучены возможности и инициальную эффективность короткого вмешательства по уменьшению риска употребления алкоголя среди взросльх в Украине. Пациентов оценивали через 3 месяй после коротких мотивачионных интервенций (КМИ или коротких интервенциий - КИ).

В исследовании использованы следующие методы: сруктуроване интервью (личные данные, употребление веществ, история лечения употребление веществ, история болезни), AUDIT-C (Alcohol Use Disorders Identification Test-Concise - шкала с 3 вопросов для скрининга паџиентов с проблемным употреблением алкоголя, что является модификацией полной шкаль AUDIT с 10 вопросов), RAPI (Rutgers Alcohol Problems Index это инструмент для скрининга (опросник) с 23 вопросов для оценки алкогольных проблем 
среди подростков), DMQ (Drinking Motives Questionnaire - это опросник на 28 пунктов, измеряюший 5 мотивов питья: социальное "улучшение", уменьшения чувства депрессии, противотревожными мотив и чувство соответствия), икала качества жизни (А. Чабан, 2009), BSSS (Brief Sensation Seeking Scale - шкала, которая помогает идентифицировать лии, ищущих острые чувстве, как рискованное поведение, употребление алкоголя и т.д.), PHQ -9 (Patient Health Questionnaire-9 - опросник для диагностики депрессии), GAD-7 (General Anxiety Disor ders -7 - опросник для диагностики тревожных расстройств), BPAQ-SF (Buss-Perry Aggression Questionnaire - опросник для оченки агрессии). Мы также оценили многие факторы, в том числе частоту посещений участниками нашей клиники после завершения пилотного исследования.

Доказано, что группа коротких интервенций (группа КI) показала значительно меньший уровень потребления алкоголя и последствия после 4-летнего периода по сравнению с контрольной группой $(p<0.001)$. Однако университетская группа показала больше случаев нарушения трезвости в этот период. Среди образиов КМИ было обнаружено более низкий уровень депрессивных и тревожных симптомов по шкалам $P H Q-$ 9 и GAD-7 относительно контрольной группь. Также группа коротких интервенщий обнаружила более высокий уровень качества жизни относительно контрольной группы. Также уровень агрессии был разным в КМИ и контрольных группах (контрольная группа показала более высокий уровень агрессии). Однако, есть некоторые различия между группами пациентов и студентов с КМИ в результатах шкалы качества жизни. Этот результат может быть связан с качеством периода трезвости в этих группах и $c$ наличием высшего уровня агрессии (включая косвенную агрессию - чувство вины, согласно BPAQ-SF) в выборке студентов.

Показано, что полученные данные свидетельствуют о перспективности КМИ как средства для снижения рискованного употребления алкоголя среди молодежи в Украине.

Ключевые слова: мотивационное интервью, молодежь, подростки, алкоголь, факторы, продолжают трезвость.

Introduction. The Global status report on alcohol and health (2018) showed discouraging data. Worldwide in 2016 , more than half (57\%, or 3.1 billion people) of the global population aged 15 years and over had abstained from drinking alcohol in the previous 12 months. But some 2.3 billion people are current drinkers (World Health Organization, 2018).

In the African, Americas, Eastern Mediterranean and European regions, the percentage of drinkers has declined since 2000.

However, it increased in the Western Pacific Region from 51.5\% in 2000 to $53.8 \%$ today and has remained stable in the South-East Asia Region.

Total alcohol per capita consumption in the world's population over 15 years of age rose from 5.5 liters of pure alcohol in 2005 to 6.4 liters in 2010 and was still at the level of 6.4 liters in 2016. Nearly all of the countries with the highest levels of alcohol consumption are located in Eastern Europe. They include Russia and other former Soviet Union nations such as Belarus, Lithuania, Moldova, and Ukraine (Ministry of Health of Ukraine, 2014).

At the same time alcohol use continues to be a major problem from preadolescence through young adulthood in the world. Results of recent neuroscience research have substantiated the deleterious effects of alcohol on adolescent brain development and added even more evidence to support the call to 
prevent and reduce under-aged drinking (Johnston L.D. et all, 2006; Wells J.E., 2004).

Worldwide, more than a quarter (26.5\%) of all 15-19-year-olds are current drinkers, amounting to 155 million adolescents. Prevalence rates of current drinking are highest among 15-19-year-olds in the WHO European Region (43.8\%), followed by the Region of the Americas (38.2\%) and the Western Pacific Region $(37.9 \%)$.

In 2016, the harmful use of alcohol resulted in some 3 million deaths $(5.3 \%$ of all deaths) worldwide and 132.6 million disability-adjusted life years (DALYs) i.e. $5.1 \%$ of all DALYs in that year. Mortality resulting from alcohol consumption is higher than that caused by diseases such as tuberculosis, HIV/AIDS and diabetes.

Specialists who works with adolescents should be knowledgeable about risk factors for alcohol and other substance abuse to recognize them among youth, provide appropriate brief interventions, and refer them to treatment (Miller, 2002). The integration of alcohol use prevention programs in the community and our educational system from elementary school through college should be promoted by psychiatrists, psychologists and the health care community or social workers. Promotion of media responsibility to connect alcohol consumption with realistic consequences should be supported by all medical doctors.

Young adults are especially interesting group to examine in Ukraine. First of all, it was because these youth were raised following the downfall of the Soviet Union in 1991 during a socio-economic downturn. Secondly, youth in Ukraine are affected by one more powerful stress factor. Namely, there is a war in Ukraine and young men are potentially soldiers. It can provoke a search of new coping mechanisms of stress (Polshkova et all, 2016).

Also, some researchers and clinicians consider binge drinking as a self-harm behavior (autoaggressive behavior). Although commonly, autoaggressive behavior has the connotation of an intentional, self-inflicted, physical injury or suicide attempt; substance use and eating disorders may be also viewed as a non-suicidal self-harm behavior. Further, some researchers consider the choice of high risk occupation (e.g., increased risk of injury including unintentional death caused by work) and the non-observance of safety rules during work as autoaggressive behaviors. The boundaries between suicide and non-suicidal autoaggressive behaviors are not always clearly defined, and in some cases behaviors that usually fall outside the boundaries of self-harm may indeed represent self-harm if performed with explicit intent to cause tissue damage (Miller et all, 2003). Presence of selfharm is listed in the DSM-IV-TR as a symptom of borderline personality disorder or it can be a comorbid disorder. The reasons for self-harm vary, as it may be used to fulfill a number of different functions. For example, it may be a coping mechanism, which provides temporary relief of strong feelings (e.g., anxiety, depression, stress, and emotional numbness, guilty feelings), a sense of failure or self-loathing, or other mental traits including low self-esteem. Self-harm is most common during adolescence and young adulthood, its habitual and usually first appearing between the ages of 12 and 24 (Brener et all, 2003). 
We consider risky drinking as a self-harm (autoaggressive) behavior. Therefore, early intervention for emerging adults with risky drinking may be a more effective use of resources than exclusive focus on treatment of those with alcohol use disorders (Nathan, 1988). A pilot study conducted in Ukraine in 2015 survey emerging adults in an inpatient hospital and University, and found that most did not think they had an alcohol problem. Further, our data showed that more frequent motives for alcohol use were related to coping with negative affect (e.g., stress, anxiety) and social influences (e.g., because my friends use alcohol). These findings are similar to that of American studies with college students, in which common motives for drinking included: coping-anxiety, coping-depression, social, enhancement, and conformity (Grant et al., 2007; Rollnick et all, 2003).

In this regard, brief motivational interventions (BMIs) may be useful to enhance desire to change behavior and address motives for use in order to reduce risk of future alcohol problems among youth. The need for early intervention may be particularly important for young adults with alcohol use and co-morbid anxiety and/or depression.

Thereby, we conducted one more pilot study in 2014-2015. Our study evaluated the efficacy of BMI by comparing BMI and no BMI conditions among two samples of youth screening positive on the prescreen survey for risky drinking. The subject pool came from the Psychoneurological Department: the first location was located in the Railway Clinical Hospital, and the second in classes in the department at Kiev National Medical University. In conclusion, BMI group (patients and students samples) showed better results in alcohol consumption and consequences compared to a control group. However, this pilot study was too short and we were able to evaluate results of BMI in 3 months after BMI procedure only.

In spite of the data of our pilot study and the available literature data about the problem of alcohol consumption we still do not have information about efficacy of BMIs to reduce alcohol and other substance use among emerging adults in Ukraine in longitudinal perspective. At the same time among emerging youth in the U.S., studies suggest BMI approaches are promising.

In Europe, studies also showed the high efficacy of BMI in youth and adults. The goal of a German study was to gain knowledge about the target group of medically referred alcohol intoxicated adolescents and young adults, and to identify the utility of the administered BMI. Namely, researchers tried to find out more about the age and gender structure of participants, their alcohol and drug use history and their history of previous incidents of acute alcohol intoxication, their risky substance use and symptoms of psychopathology. Also, they assessed how many participants of the BMI took advantage of recommended further counseling regarding their alcohol use (in a longitudinal perspective). Third, it was examined in what characteristics the group of "help accepters" - people who accepted recommendations from psychologists, differs from the group of "help avoiders" someone who denied from help, with regard to socio-demographic characteristics and substance use patterns. Yet, this research faced several limitations. First, the BMI had a disadvantage - it was only semi-structured. It was uncontrolled stage - 1design (there was not a control group); thus, researchers were not able to check and 
demonstrate the efficacy of the BMI. It remains unclear, if the BMI initiated change of motivation or had the effect of motivational enhancement. The efficacy of the subsequent youth-specific counseling services was not examined in a longitudinal perspective. Another European study illuminates the existing evidence concerning the efficacy of brief motivational intervention. Thus, there remain unanswered questions around the effectiveness of brief alcohol intervention across different settings, different population groups including emerging adults, about the optimal intervention content, and the main question is longevity of intervention effects, duration and quality of sobriety period and quality of life of BMI recipients.

Additional research into the prevention, screening and identification, brief intervention, and management and treatment of alcohol and other substance use by adolescents continues to be needed to improve evidence-based practices.

The objective of our study was to explore the efficacy of brief motivational interventions (BMIs) for treatment of young people with alcohol problems in longitudinal perspective (after 4 years). The results of previous studies indicate that brief interventions for unhealthy alcohol use have been shown to be effective in primary care settings, with most studies focusing on adults and few studies focusing on youth (Miller et all, 2003). Nowadays, no BMI studies have been conducted in Ukraine among youth with alcohol use in longitudinal perspective.

\section{Methods.}

\section{Design and Setting}

Our study evaluated the efficacy of BMI among youth screening positive on the prescreen survey for risky drinking by comparing group who received BMI with a group who did not receive BMI. Participants came from the Psychoneurological Department: the first part of group was from the Railway Clinical Hospital \#1, and the second part was from classes in the department at National Medical University named by O.O.Bogomolets.

In 2014-2015 the total sample of 120 was divided into 1.) 60 patients from Railway Clinical Hospital \#1; and 2.) 60 students from National Medical University named by O.O.Bogomolets. Participants were stratified by recruitment site and randomized to condition: BMI and control, with follow-up assessment in 3 months. In 2018-2019 we contacted our participants for taking part in the continuation of the study and evaluated them in 4 years after BMI procedure.

In addition to being the first of study to evaluate the efficacy of BMI on substance use problems among youth in Ukraine, this study examined BMI intervention processes in relation to alcohol outcomes. Findings informed research and clinical practice to enhance early identification and prevention of problematic alcohol use trajectories among emerging adults and it was a basement for our longitudinal study.

After completing our study in 2014 all our participants obtained an opportunity to visit our clinic as often as they need (for free). This opportunity helped us to keep most of our samples in our database and keep good compliance among our patients. After signing informed consent form and completing enrollment we had 94 participants (41 patients and 53 students). 
In our study we had Inclusion and Exclusion criteria. Inclusion criteria were: participants of our pilot study 2014-2015 (BMI and no-BMI samples), who are able to provide informed consent; speaks and writes Ukrainian or Russian. Exclusion criteria were: psychotic patients who need special treatment and were not able to follow the requirements of the protocol; adults who are unable to provide informed consent by hospital personnel or research staff (because of intoxication or mental incompetence), and adults with suicide attempts in their history or with suicidal thoughts in the past or present (because they present in high psychological distress requiring intensive attention and intervention by staff).

After signing an Inform Consent Form (ICF), all participants were assessed with the survey that included scales for measuring their mental state and psychological condition. First of all, patients were assessed with the AUDIT scale to identify the presence of alcohol problems. We also used RAPI scale to identify the problems caused by using alcohol. QL scale to evaluate quality of life of our patients. DMQ-R was used to know more about drinking motives of our participants. Also we evaluated the severity of depression (PHQ-9) and anxiety (GAD-7). BSSS - brief sensation seeking scale was used to screen risky behavior. Our patients filled in sleep problems questionnaire and sexual risky behavior questionnaire. With the Buss Perry Aggression Questionnaire (BPAQ) we evaluated the level of aggression of our patients (Buss et all, 1992; Hamilton, 1959; Irwin et all, 1988). Number of abstinent days was calculated as one of the treatment outcomes.

We used an electronic survey on Qualtrics online. That helped us to decrease the loss of patients from the study. For example, if patients or students didn't have time to visit the clinic or school for the visit we could send the link to this survey and he/she could answer all questions from home.

\section{BMI Description}

The BMI was delivered using a motivational interviewing framework, in which a team of four psychologists and/or psychiatrists explored the participant's motivation to change, as opposed to being prescriptive to a specific course of action (Jessor, 1991), with ambivalence about change being viewed as dynamic and common. The BMI session consisted of a 50 minute in-person session at a baseline visit (in 2014-2015) structured using a booklet. Then, there was conducted a 10-15 minute booster session (2-4 weeks after baseline visit) when we called the participant and supported them. Given expected ambivalence, the BMI and booster elicited the participant's perspective about stopping or changing their alcohol use (Baumrid, 1991), while avoiding stigmatizing them as alcoholics, problem drinkers, or in denial. Instead, the session were based on the premise that if participants do not feel judged, most will be open to at least discussing their alcohol or drug use and possibly considering the goal of avoiding future injuries and hospitalization.

Our BMI included three steps. The first step was «Ask About Alcohol Use and Assess». We asked our participants «Do you sometimes drink beer, wine, or other alcoholic beverages?» Considering the fact that all participants included into the study drank alcohol (inclusion criteria), they answered «Yes». The next question was about heavy drinking days: «How many times in the past year have you had more than 4 drinks in a day?» We tried to determine whether, in the past 12 months, 
our participants' drinking has repeatedly caused or contributed to risk of bodily harm (drinking and driving, operating machinery, swimming), relationship trouble (family or friends), role failure (interference with home, work, or school obligations), or runins with the law (arrests or other legal problems). One or more positive answers may indicate alcohol abuse (Kirkcaldy et all, 2002; Stolle et all, 2013; O'Donnell et all, 2013).

Also, we identified whether, in the past 12 months, our participants have not been able to stick to drinking limits or cut down/stop drinking, shown tolerance or signs of withdrawal, kept drinking despite problems, spent a lot of time drinking, and less time on other matters (Fleming et all, 1991). Three or more positive answers may indicate alcohol dependence whereas fewer positive answers may indicate risky drinking. Thus, during this step we tried to understand the nature of their alcohol problems and raise the possible of change as a possibility in order to proceed to the next step (Polshkova et all, 2014; White et all, 1989; Cooper et all, 1992; Zuckerman, 1994).

The second step was «Advise and Assist». We summarized consequences and medical concerns, made recommendations for reducing or stopping drinking, and identified their readiness to change drinking habits. If the participant was ready to commit to change, we helped to set a goal, agreed on a plan and provided them with educational materials. If not, we restated our concerns, encouraged reflections, identified barriers to change, and rearmed our willingness to help. The third step was «Continue Support». At this stage, we tried to determine if the participant was able to meet and sustain the chosen drinking goal. If yes, we reinforced and supported continued adherence to recommendations, renegotiating drinking goals as indicated (e.g., if the medical condition changes or if an abstaining patient wishes to resume drinking), encouraged them to return if unable to maintain goal, with recommendations for rescreening at least annually. If not, we acknowledged that changes are difficult, supported positive changes and addressed barriers, renegotiated goals and plans, considered a trial of abstinence and engaging significant others, and reassessed diagnosis if they were unable to either cut down or abstain.

\section{Statistical Design}

Data from computer surveys were transferred to SAS software version 9.2 (SAS Institute, Inc., Cary, NC) for analyses. To begin, we compared the two samples, patients and students (e.g., chi-square, t-tests). Next, regression analyses (e.g., Poisson, negative binomial, or logistic, based on variable examined) were conducted (for the combined total sample, and separately for patients and students) predicting alcohol consumption, non-drinking days, and consequences, with treatment group (BMI vs. control) as a predictor variable and including baseline levels of the variable examined. Next, regression analyses were used to examine the effects of the BMI (vs. control) on secondary outcomes of other drug use (non-drug use days, DAST-10 score), including baseline levels of the variable examined. Finally, regression analyses were used to explore the effects of the BMI (vs. control) on other outcomes including depression, anxiety, aggression, sensation seeking, 
number of sexual partners, and quality of life (including baseline level of the variable examined).

Results. As we described our participants - all of them took part in our pilot study in 2014-2015. We enrolled 41 patients (previous sample included 59 patients), 26 of them obtained BMI in 2014, and 15 - no BMI sample (control group); and 53 students (previous sample included 61 students), 32 of them - BMI sample, and 21 no BMI sample.

As compared to participants in the hospital setting, participants from the university setting were still significantly younger (similar to 2014-study results). Fewer students were married or lived together with a partner, with fewer children (table 1). If you look at dynamic from 2014 to 2018, patients had tendency to increasing the rate of marital status and having more kids, opposite to students. As a result, this difference between hospital's and university's samples in marital status just increased, then students had less marital support to cope with the desire to drink.

The next rate is «Incomplete University» significantly decreased in university samples, as we can understand as a natural factor (students completed education since 2014 to 2018).

Then we evaluated the primary efficacy outcomes. Regression analyses were conducted, separately for each setting, predicting alcohol outcomes (consumption, nondrinking days and consequences); models controlled for baseline alcohol levels and condition assignment (brief intervention or control). As you could see from our pilot study, in the combined sample (patients and students), the brief intervention group showed significantly less alcohol consumption and consequences and more non-drinking days at 3 -months as compared to the control group ( $\mathrm{p}<0.001)$ table 2 . Note that these findings were also significant when examining the hospital and university samples separately. Namely, alcohol consumption in 4-years was almost two times higher among students than patients in general (BMI and no BMI), and even 1.5 times higher in students' sample who obtained BMI compare to patients who had BMI.

Also, in our pilot study, exploratory analyses showed that there were significant decreases of depression, anxiety, physical aggression, verbal aggression, anger, hostility, and sensation seeking in the BMI group as compared to the control group; quality of life significantly increased in the BMI group as compared to the control group. 4-Years follow-up visit showed the same tendency, excepting sensation seeking (this rate was not significantly different in BMI and control groups) table 2.

However university setting showed more cases of sobriety disruption during 4-Years period. We can consider this fact because in the students' social environments the alcohol frequently accompanies socializing. At the same time most of students were single so they had a lack of marital support to cope with a desire to drink alcohol. 
Table 1

\section{Baseline Background, Violence and Substance Use Characteristics}

\begin{tabular}{|c|c|c|c|c|c|c|}
\hline \multirow{2}{*}{$\begin{array}{l}\text { Characteris } \\
\text { tics }\end{array}$} & \multicolumn{2}{|c|}{ Patients } & \multicolumn{2}{|c|}{ Students } & \multicolumn{2}{|c|}{ Total } \\
\hline & $\begin{array}{c}2014 \\
(N=59)\end{array}$ & $\begin{array}{c}2018 \\
(N=41)\end{array}$ & $\begin{array}{c}2014 \\
(N=61)\end{array}$ & $\begin{array}{c}2018 \\
(\mathrm{~N}=53)\end{array}$ & $\begin{array}{c}2014 \\
(\mathrm{~N}=120)\end{array}$ & $\begin{array}{c}2018 \\
(\mathrm{~N}=94)\end{array}$ \\
\hline $\begin{array}{l}\text { Age (mean, } \\
\text { SD) }\end{array}$ & $22.6(2.2)$ & $26.6(2.3)$ & $20.1(2.3)$ & $24.1(2.2)$ & $21.3(2.5)$ & $25.3(2.4)$ \\
\hline Male $(\mathrm{n}, \%)$ & $\begin{array}{c}27(45.8 \\
\%)\end{array}$ & $18(43.9 \%)$ & $\begin{array}{c}27 \\
(44.3 \%) \\
\end{array}$ & $28(52.8 \%)^{*}$ & $\begin{array}{c}66 \\
(55.0 \%) \\
\end{array}$ & $46(48.9 \%)^{*}$ \\
\hline $\begin{array}{l}\text { Married or } \\
\text { Living } \\
\text { together }\end{array}$ & $\begin{array}{c}36 \\
(61.0 \%)\end{array}$ & $39(95.1 \%)^{*}$ & $\begin{array}{c}39 \\
(63.9 \%)\end{array}$ & $33(62.3 \%)$ & $\begin{array}{c}75 \\
(62.5 \%)\end{array}$ & $72(76.6 \%)^{*}$ \\
\hline $\begin{array}{l}\text { Incomplete } \\
\text { University }\end{array}$ & $\begin{array}{c}22 \\
(37.3 \%)\end{array}$ & $20(48.8 \%)^{*}$ & $\begin{array}{c}61 \\
(100 \%)\end{array}$ & $24(45.3 \%)^{*}$ & $\begin{array}{c}83 \\
(69.2 \%)\end{array}$ & $44(46.8 \%)^{*}$ \\
\hline $\begin{array}{l}\text { Have } \\
\text { Child(ren) }\end{array}$ & $\begin{array}{c}33 \\
(55.9 \%)\end{array}$ & $31(75.6 \%)^{*}$ & $\begin{array}{c}22 \\
(36.1 \%)\end{array}$ & $27(50.9 \%)^{*}$ & $\begin{array}{c}55 \\
(45.8 \%)\end{array}$ & $58(61.7 \%)^{*}$ \\
\hline $\begin{array}{l}\text { Alcohol } \\
\text { Consumption } \\
\text { (AUDIT-C } \\
\text { score) } \\
\end{array}$ & $5.6(0.9)$ & $2.7(1.5)$ & $5.7(0.8)$ & $4.6(1.4)$ & $5.6(0.8)$ & $3.7(1.8)$ \\
\hline $\begin{array}{l}\text { Alcohol } \\
\text { Consequences } \\
\text { (RAPI score) }\end{array}$ & $\begin{array}{l}16.9 \\
(4.0)\end{array}$ & $14.3(3.8)$ & $\begin{array}{l}17.4 \\
(3.7)\end{array}$ & $15.7(3.9)$ & $17.2(3.8)$ & $15.1(4.0)$ \\
\hline $\begin{array}{l}\text { Non-Drinking } \\
\text { Days (Past } 30 \\
\text { days) }\end{array}$ & $3.3(1.3)$ & $9.1(1.2)$ & $3.2(1.3)$ & $6.4(1.3)$ & $3.2(1.4)$ & $7.8(1.3)$ \\
\hline Quality of Life & $\begin{array}{l}22.2 \\
(3.1)\end{array}$ & $26.4(2.7)$ & $\begin{array}{l}22.8 \\
(3.0)\end{array}$ & $25.4(2.5)$ & $22.5(3.0)$ & $25.9(3.0)$ \\
\hline $\begin{array}{l}\text { Depression } \\
\text { (PHQ-9) }\end{array}$ & $8.1(4.0)$ & $4.2(3.6)$ & $8.2(3.4)$ & $6.5(4.3)$ & $8.2(3.7)$ & $5.9(3.7)$ \\
\hline Anxiety & $\begin{array}{l}12.2 \\
(3.3)\end{array}$ & $7.5(2.7)$ & $\begin{array}{l}13.0 \\
(3.1)\end{array}$ & $8.2(3.0)$ & $12.6(3.2)$ & $7.9(2.9)$ \\
\hline $\begin{array}{l}\text { Sensation } \\
\text { Seeking }\end{array}$ & $\begin{array}{l}25.9 \\
(4.0) \\
\end{array}$ & $18.7(3.5)$ & $\begin{array}{l}26.3 \\
(3.6) \\
\end{array}$ & $23.1(3.0)$ & $26.1(3.8)$ & $20.7(3.0)$ \\
\hline \multicolumn{7}{|c|}{ Violence-Related Variables } \\
\hline $\begin{array}{l}\text { Physical } \\
\text { Aggression }\end{array}$ & $\begin{array}{l}29.3 \\
(5.0) \\
\end{array}$ & $22.3(3.7)$ & $\begin{array}{l}30.3 \\
(4.2) \\
\end{array}$ & $28.4(4.0)$ & $29.8(4.7)$ & $25.1(3.4)$ \\
\hline $\begin{array}{l}\text { Verbal } \\
\text { Aggression }\end{array}$ & $\begin{array}{l}15.9 \\
(3.2)\end{array}$ & $13.2(2.1)$ & $\begin{array}{l}17.0 \\
(2.3)\end{array}$ & $14.3(2.4)$ & $16.5(2.8)$ & $13.6(2.20)$ \\
\hline Anger & $\begin{array}{l}21.5 \\
(3.3)\end{array}$ & $17.2(2.3)$ & $\begin{array}{l}22.9 \\
(2.6)\end{array}$ & $20.7(2.1)$ & $22.2(3.0)$ & $18.2(2.6)$ \\
\hline Hostility & $\begin{array}{l}25.6 \\
(4.7)\end{array}$ & $19.1(1.9)$ & $\begin{array}{l}27.4 \\
(3.7)\end{array}$ & $25.3(2.0)$ & $26.5(4.3)$ & $23.2(2.0)$ \\
\hline
\end{tabular}


Table 2

\section{Descriptive Data at Baseline, 3-Month Follow-up (N=120), and 4-Years Follow-up ( $\mathrm{N}=94)$}

\begin{tabular}{|c|c|c|c|c|c|}
\hline Variable & Group & $\begin{array}{c}\text { Baseline, } \\
\text { Mean (SD) }\end{array}$ & $\begin{array}{l}\text { 3M Follow- } \\
\text { up, Mean } \\
\text { (SD) }\end{array}$ & $\begin{array}{l}\text { 4Y Follow- } \\
\text { up, Mean } \\
\text { (SD) }\end{array}$ & $\begin{array}{c}\text { Regression, } \\
\text { IRR }\end{array}$ \\
\hline \multirow{2}{*}{$\begin{array}{l}\text { Alcohol } \\
\text { Consumption }\end{array}$} & BMI & $5.6(0.7)$ & $1.5(1.5)$ & $2.2(0.9)$ & \multirow{2}{*}{$\begin{array}{l}0.37(0.31- \\
0.67)^{* * *}\end{array}$} \\
\hline & Control & $5.6(0.9)$ & $5.0(1.8)$ & $5.3(1.5)$ & \\
\hline \multirow{2}{*}{$\begin{array}{l}\text { Alcohol } \\
\text { Consequences }\end{array}$} & BMI & $17.0(3.6)$ & $10.3(5.9)$ & $13.4(3.8)$ & \multirow{2}{*}{$\begin{array}{l}0.24(0.27- \\
033)^{* * *}\end{array}$} \\
\hline & Control & $17.3(4.1)$ & $19.3(4.6)$ & $17.1(2.4)$ & \\
\hline \multirow{2}{*}{$\begin{array}{l}\text { Non-Drinking } \\
\text { Days }\end{array}$} & BMI & $3.3(1.3)$ & $11.4(3.5)$ & $10.5(2,7)$ & \multirow{2}{*}{$\begin{array}{l}2.01(1.75- \\
2.30)^{* * *}\end{array}$} \\
\hline & Control & $3.2(1.3)$ & $5.7(3.0)$ & $5.2(2,5)$ & \\
\hline \multirow{2}{*}{ Depression } & BMI & $8.0(3.3)$ & $2.1(3.3)$ & $3.6(1,8)$ & \multirow{2}{*}{$\begin{array}{l}0.21(0.12- \\
0.22)^{* * *}\end{array}$} \\
\hline & Control & $8.3(4.1)$ & $6.9(3.2)$ & $7.7(2.6)$ & \\
\hline \multirow[b]{2}{*}{ Anxiety } & BMI & $12.5(3.0)$ & $2.7(3.4)$ & $4.9(2.8)$ & \multirow{2}{*}{$\begin{array}{l}0.72(0.52- \\
0.85) * * *\end{array}$} \\
\hline & Control & $12.7(3.4)$ & $6.4(2.5)$ & $10.7(3.1)$ & \\
\hline \multirow{2}{*}{ Sensation Seeking } & BMI & $26.5(3.7)$ & $16.5(4.6)$ & $18.4(1.8)$ & \multirow{2}{*}{$\begin{array}{l}0.39(0.33- \\
0.44)^{* * *}\end{array}$} \\
\hline & Control & $25.8(3.8)$ & $23.8(5.2)$ & $22.9(0.7)$ & \\
\hline \multirow{2}{*}{ Quality of Life } & BMI & $22.7(3.0)$ & $30.7(3.6)$ & $29.3(3.1)$ & \multirow{2}{*}{$\begin{array}{l}0.70(0.62- \\
0.81)^{* * *}\end{array}$} \\
\hline & Control & $22.3(3.1)$ & $23.7(3.1)$ & $22.6(2.7)$ & \\
\hline \multirow{2}{*}{$\begin{array}{l}\text { Physical } \\
\text { Aggression }\end{array}$} & BMI & $29.5(4.5)$ & $19.5(5.6)$ & $17.2(0.3)$ & \multirow{2}{*}{$\begin{array}{l}0.69(0.62- \\
0.78)^{* * *}\end{array}$} \\
\hline & Control & $30.1(4.8)$ & $28.0(3.7)$ & $33.1(0.7)$ & \\
\hline \multirow{2}{*}{ Verbal Aggression } & BMI & $16.2(2.9)$ & $10.8(3.7)$ & $12.3(2.4)$ & \multirow{2}{*}{$\begin{array}{l}0.67(0.61- \\
0.76)^{* * *} \\
\end{array}$} \\
\hline & Control & $16.7(2.7)$ & $15.8(2.1)$ & $15.0(1.7)$ & \\
\hline \multirow{2}{*}{ Anger } & BMI & $21.9(3.2)$ & $17.0(4.4)$ & $17.9(2.3)$ & \multirow{2}{*}{$\begin{array}{l}0.38(0.32- \\
0.55)^{* * *}\end{array}$} \\
\hline & Control & $22.5(2.9)$ & $21.8(2.4)$ & $18.5(0.7)$ & \\
\hline \multirow{2}{*}{ Hostility } & BMI & $26.3(4.6)$ & $17.2(5.5)$ & $18.9(2.7)$ & \multirow{2}{*}{$\begin{array}{l}0.58(0.54- \\
0.78) * * *\end{array}$} \\
\hline & Control & $26.9(3.9)$ & $25.2(3.3)$ & $27.5(0.3)$ & \\
\hline
\end{tabular}

Discussion. Data from our pilot study and its continuation contributes to the literature by examining screening and brief intervention approaches adapted to a specific cultural context, namely emerging adulthood in the Ukraine.

Although replication is required, results suggest that BMI approaches may be efficacious for reducing risky drinking and consequences in the short term (e.g., 3months) and long-term (e.g., 4-years) among emerging adults in both university and inpatient hospital settings.

In addition to being the first of studies on this topic in the Ukraine, these studies also explored intervention effects on other outcomes to help understand potential mechanisms underlying changes following BMI. Together, these findings inform research and clinical practice to enhance early identification in order to potentially alter problematic alcohol use trajectories among emerging adults in the Ukraine. 
Data from our pilot study showed that as compared to a control group the BMI, which included a telephone booster, reduced alcohol consumption and consequences, and increased non-drinking days, among both the university and hospital samples. Thus, even though clinician's noted that patients of the hospital sample seemed more receptive to the BMI, whereas the university students were less enthusiastic, both samples reduced their alcohol consumption. Our longitudinal study showed that the effect of BMI lasts for some years, especially in hospital setting compare to university setting. The sample differences, in which students were younger and single, did not appear to affect the efficacy of the BMI on alcohol outcomes but the marital status and high level of aggression caused sobriety disruption in university setting. These findings are consistent with the literature in which BMIs are effective for reducing alcohol consumption in clinic and university samples (Miller et all, 2002; Miller et all, 2003; Brener et all, 2003).

Future studies are needed to determine how this intervention can be adapted to reduce other drug use in the Ukraine. Also, it was important to discuss social support for abstinence, and reduced drinking, as it is uncommon for young people to abstain in Ukraine.

Under the war conditions in the Ukraine, young people may be particularly receptive to BMIs which are free care, which may explain the positive outcomes from the BMI found in this study. Future studies are needed during peacetime conditions.

We explored the effects of the BMIs on other related factors to provide clues to potential mechanisms of BMI effects. Caution is required when interpreting these findings, however, given their exploratory nature, the small sample size, and the design, which precluded complex statistical modeling (e.g., mediation/moderation) and causal determination. As compare to the controls, the BMI reduced depression, anxiety, anger, aggression, and sensation seeking (in 3-months term), but increased quality of life. These findings are consistent with the focus of the BMI, which included alternatives for coping with negative affect and alternative ways to have fun and enjoy life. Moreover, this effect lasts for years; BMI helps patients to cope with negative emotions ignoring their typical habit - to drink alcohol. Future research is needed to examine the importance of these factors in sustaining reductions in drinking.

Conclusions. Ideally, clinicians should be knowledgeable about substance abuse to be able to recognize risk factors for alcohol and other substance use among adolescents and emerging adults, screen for use, provide appropriate brief interventions, and refer to treatment. Once replicated, study findings support the integration of alcohol use prevention programs into the medical and educational system among emerging adults in the Ukraine. Further research is needed to replicate and extend these promising findings with other samples of adolescents and emerging adults in various healthcare and educational settings in Ukraine. 


\section{References}

1. Baumrid, D. (1991). The influence of parenting style on adolescent competence and substance use. $J$ Early Adolesc., 11(1), 56-95.

2. Brener, N.D, Billy, J.O., \& Grady, W.R. (2003). Assessment of factors affecting the validity of self-reported health-risk behavior among adolescents: evidence from the scientific literature. The Journal of adolescent health: official publication of the Society for Adolescent Medicine, 33(6), 436-457.

3. Buss, A.H., \& Perry M. (1992). The aggression questionnaire. Journal of Personality and Social Psychology, 63, 452-459.

4. Cooper, L.M., Russel M., Skinner J.B. \& Windle M. (1992). Development and validation of a three-dimensional measure of drinking motives. Psychological Assessment, 4(2), 123-132.

5. Fleming, M.F., Barry, K.L., \& MacDonald, R. (1991). The alcohol use disorders identification test (AUDIT) in a college sample. Int $J$ Addict, 26(11), 1173-85.

6. Hamilton, M. (1959). The assessment of anxiety states by rating. Br J Med Psychol., 1, 50-55.

7. Irwin, M., Baird, S., Smith, T.L., \& Schuckit, M. (1988). Use of laboratory tests to monitor heaving drinking by alcoholic men discharged from a treatment program. Am J Psychiatry, 145 (5), 595-599.

8. Jessor, R. (1991). Risk behavior in adolescence: A psychosocial framework for understanding and action. J Adolesc Health, 12(8), 597-605.

9. Johnston L.D., O'Malley P.M., Bachman J.G., \& Schulenberg J.E. Monitoring the Future national survey results on drug use, 1975-2006.Volume 1: Secondary school students. National Institute on Drug Abuse; 2007. NIH Publication No. 07-6205.

10. Kirkcaldy B.D., Shephard R.J., \& Siefen R.G. (2002). The relationship between physical activity and self-image and problem behavior among adolescents. Soc Psychiatry PsychiatrEpidemiol, 37(11), 544-550.

11. Miller, W.R., \& Rollnick, S. (2002). Motivational Interviewing: Preparing People for Change. 2nd ed. New York, NY: Guilford Press.

12. Miller, W.R., Wilbourne, P.L., \& Hettema, J.E. (2003). What works? A summary of alcohol treatment outcome research. In: Hester RK, Miller WR, (Eds.). Handbook of Alcoholism Treatment Approaches: Effective Alternatives. 3rd ed. Boston, MA: Pearson Education.

13. Ministry of Health of Ukraine. Official site http://www.moz.gov.ua/ua/portal/ Published October 22, 2010. Accessed January 6, 2014.

14. Bertholet N., Palfai T., \& Gaume J., et al. (2013). Do Brief Alcohol Motivational Interventions Work Like We Think They Do? Alcoholism: clinical and experimental research, 1, 1-7.

15. O'Donnell A., Anderson P., Newbury-Birch D. et al. The Impact of Brief Alcohol Interventions in Primary Healthcare: A Systematic Review of Reviews http://alcalc.oxfordjournals.org/content/early/2013/11/13/alcalc.agt170.full

16. Polshkova, S., Chaban, O., \& Walton, M.A. (2016). Alcohol use, depression, and high risk occupations among young adults in the Ukraine. Substance Use \& Misuse, 51:7, 948951. doi: $10.3109 / 10826084.2016 .1156700$

17. Polshkova, S., Voloshyna, D., Cunningham, R.M., Zucker, R.A., \& Walton, M.A. (2016). Prevention of alcohol and other drug use using motivational interviewing among Young Adults in the Ukraine. Psychosomatics: Science and Practice, 1, 1-6.

18. Rollnick, S., Miller, W., \& Butler, C. (2007). Motivational interviewing in health care: Helping patients change behavior. New York: Guilford.

19. Knauer, C. (2003). Geriatric alcohol abuse: a national epidemic. Geriatric Nursing (New York, N.Y.), 24(3), 152-154. 
20. Stolle, M., Sack, P.M., Broening, S., Baldus, C., \& Thomasius, R. (2013). Brief Intervention in Alcohol Intoxicated Adolescent-A Follow-up Study in an Accessto-Care Sample. J Alcoholism Drug Depend, 1, 106. doi: 10.4172/2329-6488.1000106.

21. Wells, J.E., Horwood, L.J., \& Fergusson, D.M. (2004). Drinking patterns in mid-adolescence and psychosocial outcomes in late adolescence and early adulthood. Addiction, 99(12), 1529-1541. 22. White, H.R., Labouvie, E.W. (1989). Towards the assessment of adolescent problem drinking. Journal of Studies on Alcohol, 50, 30-37.

23. World Health Organization (WHO). (2018). Global status report on alcohol and health. Geneva, Switzerland: World Health Organization. https://www.who.int/healthtopics/alcohol\#tab=tab_1,

24. Zuckerman, M. (1994). Behavioral expressions and biosocial bases of sensation seeking. Cambridge University Press, New York, NY.

\section{Відомості про авторів}

Полшкова Світлана, доктор медичних наук, проректор 3 наукової роботи Київського інституту сучасної психології та психотерапії, лікар-психіатр, психотерапевт, м. Київ, Україна.

Polshkova, Svitlana, $\mathrm{PhD}$ in Medicine, Vice Rector for science Kyiv institute modern psychology and psychotherapy, psychotherapist, Kyiv, Ukraine.

ORCID ID: https://orcid.org/0000-0001-6433-9677

E-mail: s_polshkova@yahoo.com

Чабан Олег, доктор медичних наук, професор, завідувач кафедри медичної психології, психосоматичної медицини та психотерапиї Національного медичного університету ім. О.О. Богомольця, лікар-психіатр, психотерапевт, м. Київ, Україна.

Chaban Oleg, professor, Head of Department of Medical psychology, psychosomatic medicine and psychotherapy of National medical university named by O.O. Bogomolets, psychiatrist, psychotherapist, Kyiv, Ukraine.

ORCID ID: https://orcid.org/0000-0001-9702-7629

E-mail: ocs@ukr.net

Отримано 20 липня 2020 р.

Рецензовано 10 серпня 2020 .

Прийнято 01 вересня 2020 р. 